\title{
Potential of Integrated Use of Bacillus sp. AZ6 and Organic Waste for Zinc Bio-Activation to Improve Physiological Attributes of Maize
}

\author{
Azhar Hussain ${ }^{1 *}$, Xuikang Wang ${ }^{2 * *}$, Zahir Ahmad Zahir ${ }^{3}$, Khadija Mahmood ${ }^{1}$, \\ Muhammad Zahid Mumtaz ${ }^{4}$, Muhammad Saqib5, Muhammad Usman Jamshaid ${ }^{6}$, \\ Hafiz Tanvir Ahmad ${ }^{7}$
}

${ }^{1}$ Department of Soil Sciences, The Islamia University of Bahawalpur, 63100-Pakistan

${ }^{2}$ College of Life Sciences, Yan'an University, Yan'an 716000, China

${ }^{3}$ Institute of Soil and Environmental Sciences, University of Agriculture Faisalabad, 38040-Pakistan ${ }^{4}$ Institute of Molecular Biology and Biotechnology, The University of Lahore, Main Campus, Lahore, 54000-Pakistan

${ }^{5}$ Department of Agronomy, The Islamia University of Bahawalpur, 63100-Pakistan

${ }^{6}$ Department of Soil and Environmental Sciences, MNS, University of Agriculture Multan, Pakistan

${ }^{7}$ Soil and Water Testing Laboratory, Kasur, Govt. of Punjab, Pakistan

Received: 11 April 2021

Accepted: 18 September 2021

\begin{abstract}
Zinc $(\mathrm{Zn})$ is an important micronutrient for plant physiology, including the activation of various enzymes, nitrogen metabolism, cell-membrane integrity, and carbonic anhydrase activity. Its deficiency is reported in plants grown in poor soils worldwide including Pakistan. Exogenous application of $\mathrm{Zn}$ fertilizers is not efficient due to fixation into the soil. Thus, $\mathrm{Zn}$ solubilizing bacteria have a stronger power to chelates the insoluble $\mathrm{Zn}$ compounds which may increase $\mathrm{Zn}$ availability for plant uptake. Therefore, a pot trial was conducted to evaluate the effects of four products of bio-activated zinc oxide $(\mathrm{ZnO})$ formulated using bio augmented-organic matter coated with zinc oxide (BOZ) on the physiological attributes of maize. Four different products viz. BOZ1, BOZ2, BOZ3, and BOZ4 were prepared using Bacillus sp. AZ6 strain augmented orange peel and $\mathrm{ZnO}$. The results revealed that BOZ4 formulation performed outclass by exhibiting $85 \%, 31 \%$, and $108 \%$ higher photosynthetic rate, stomatal conductance, and transpiration rate, respectively, compared to control. Likewise, it showed a maximum increase in carbonic anhydrase activity, vapor pressure deficit, electrolyte leakage, and SPAD value by $74 \%, 44 \%, 45 \%$, and $66 \%$, respectively, over control. Hence, it is concluded that bio-activation of $\mathrm{ZnO}$ by Bacillus sp. AZ6 and orange-peel waste could serve as an effective strategy to improve the physiology of maize.
\end{abstract}

Keywords: Bacillus sp., bio-activation, carbonic anhydrase, zinc solubilizing bacteria, zinc oxide, maize crop, bioaugmented-organic matter

\footnotetext{
*e-mail: azharhaseen@gmail.com

**e-mail: wangxiukang@yau.edu.cn
} 


\section{Introduction}

Zinc $(\mathrm{Zn})$ is an important micronutrient needed by all the organisms including microorganisms, humans, animals, and plants. It is an important component of various enzymes which catalyze many metabolic reactions in plants [1]. It is essential for nitrogen (N) metabolism, uptake of $\mathrm{N}$, synthesis of protein, chlorophyll, carbonic anhydrase (CA) activity, and resistance against biotic, abiotic, and oxidative stresses [2]. Zn also plays a significant role in photosynthesis, cell membrane integrity, pollen formation and enhances the antioxidant enzymes activity as well as chlorophyll contents within plant tissues [3, 4]. It constitutes more than 300 enzymes as a core co-factor for their activation [5]. The catalytic activities of all the enzymes is badly affected by the $\mathrm{Zn}$ deficiency in addition to their metabolic reactions [6]. The $\mathrm{CA}$ is a metalloenzyme and participates in $\mathrm{pH}$ adjustment, transfer of $\mathrm{CO}_{2}$, ion exchange, respiration, photosynthetic $\mathrm{CO}_{2}$ fixation, and closure of stomata. $\mathrm{Zn}$ catalysis $\mathrm{CA}$ as a cofactor by binding with water and activating the catalytic site of the enzyme. Zn deficiency lessens the CA content in plants [7].

Maize is counted as one of the imperative cereal crops worldwide and its total production is greater than other cereal grains [8]. It is most susceptible to $\mathrm{Zn}$ deficiency thus shows stunted growth under $\mathrm{Zn}$ deficiency. In Pakistan, $\mathrm{Zn}$ is deficient due to its precipitation in soils, which results in limited $\mathrm{Zn}$ availability to plants consequently leading to poor roots development [9]. Therefore, the application of inorganic fertilizers could be a good source of $\mathrm{Zn}$ for enhancing crop production; however, due to its fixation in alkaline and calcareous soils, it is not economical practice [10]. It is well-understood that $90 \%$ of applied $\mathrm{Zn}$ fertilizer in calcareous soils is precipitated and adsorbed on soil colloids [11]. Two sources of $\mathrm{Zn}$ including zinc oxide $(\mathrm{ZnO})$ and zinc sulfate $\left(\mathrm{ZnSO}_{4}\right)$ having $80 \%$ and $33 \%$ of $\mathrm{Zn}$ are mostly applied as $\mathrm{Zn}$ fertilizers. Plants uptake $\mathrm{Zn}$ in its soluble form, $\mathrm{Zn}^{2+}$, but a significant amount of $\mathrm{Zn}$ in the soil that is insoluble. Overall, lower $\mathrm{Zn}$ contents, soil alkalinity, high calcite content, high bicarbonate ion levels, and high phosphorus levels are the primary physicochemical soil factors that cause Zn deficiency in staple foods $[12,13]$.

The efficiency of $\mathrm{ZnO}$ (an insoluble and costeffective source) can be enhanced through bio-activation with bacteria and organic amendments $[14,15]$. The bio-activation of $\mathrm{Zn}$ through $\mathrm{Zn}$ solubilizing bacteria (ZSB) strains had been previously reported by Hussain et al. [16], Hussain et al. [17], Nazir et al. [18], Ain et al. [19]. Generally, the ZSB plant growth-promoting rhizobacteria (PGPR) bio-activate $\mathrm{Zn}$ through chelating the metal compounds by protonation and production of organic acids [20]. Lowering the soil $\mathrm{pH}$ through the production of organic acid by bacteria can increase the bioavailability of $\mathrm{Zn}$ [21]. In general, small changes in soil $\mathrm{pH}$ can dramatically change the release of different micronutrients in the soil, particularly the bioavailability of $\mathrm{Zn}$ increases by a factor of 100 as the $\mathrm{pH}$ decreases by 1 unit and conversely. Previously, the inoculation with organic acid-producing bacteria showed improvement in bioavailable $\mathrm{Zn}$ contents in rhizospheric soil and plant tissues [22]. The bacterial genus Bacillus and Pseudomonas showed their potential to dissolve insoluble $\mathrm{Zn}$ sources such as $\mathrm{ZnO}$ and $\mathrm{ZnCO}_{3}$ [23]. Such bacteria are multifaceted having characteristics of $\mathrm{N}_{2}$ fixation, solubilization of minerals, production of phytohormones, siderophores, organic acids, and are involved in an antagonistic activity that can improve plant growth even under biotic and abiotic stresses [14, 24, 15]. The use of Zn-solubilizing plant growth-promoting microbial inoculants in agriculture has been related to a substantial increase in crop yield $[25,26]$.

Therefore, the current pot study was conducted to demonstrate the hypothesis that integrating ZSB strain with organic material and chemical $\mathrm{Zn}$ source could improve maize physiology. In the present study, various formulations of Bacillus sp. AZ6 strain, organic matter, and $\mathrm{ZnO}$ were produced and applied in a pot trial to investigate their effects on maize physiology. The formulated products showed promising results and improved the maize physiology in terms of gas exchange attributes, carbonic anhydrase activity, leaf chlorophyll contents, and electrolytes leakages.

\section{Materials and Methods}

\section{Production of Bioaugmented-Organic Matter Coated with $\mathrm{ZnO}$}

The bioaugmented-organic matter coated with $\mathrm{ZnO}$ (BOZ) products were formulated using the method of Hussain et al. [16], Hussain et al. [17]. Pre-isolated PGPR strain Bacillus sp. AZ6 having Accession No. KT221633 [14] was selected for the preparation of BOZ. The strain was grown in DF (Dwarkin and Foster) minimal media for $48 \mathrm{~h}$ at $30 \pm 1^{\circ} \mathrm{C}$. Orange peel collected locally was inoculated with strain AZ6 at 90:10 ratio (w/v; orange peel: bacterial culture) and kept in an incubator at $30 \pm 1^{\circ} \mathrm{C}$ for $72 \mathrm{~h}$. The $\mathrm{ZnO}$ powdered bulk was mixed with different ratios of inoculated orange peel to achieve different BOZ formulations viz. BOZ1 (90:10 ratio; w/w; bioaugmented orange peel: $\mathrm{ZnO}$ ratio), BOZ2 (80:20 ratio; w/w; bioaugmented orange peel: $\mathrm{ZnO}$ ratio), $\mathrm{BOZ3}$ (70:30; w/w; bioaugmented orange peel: $\mathrm{ZnO}$ ratio), and BOZ4 (60:40; w/w; bioaugmented orange peel: $\mathrm{ZnO}$ ratio). To achieve chelation of $\mathrm{Zn}$ with strain AZ6 and orange peel, the prepared formulations were further stored at $30 \pm 1^{\circ} \mathrm{C}$ for 3 days. $\mathrm{Zn}$ concentration in $\mathrm{BOZ}$ products was determined through atomic absorption spectrophotometer (240 FS) after the acid digestion method [27]. The BOZ formulations showed a $\mathrm{Zn}$ 
concentration of $9.8 \%$ in BOZ1, $19.7 \%$ in BOZ2, $29.6 \%$ in $\mathrm{BOZ3}$, and $39.5 \%$ in $\mathrm{BOZ} 4$. The $\mathrm{pH}$ of formulated products $\mathrm{BOZ1}, \mathrm{BOZ2}, \mathrm{BOZ3}$, and BOZ4 were 5.1, 5.1, 4.9 , and 4.8, respectively $[16,17]$.

\section{Pot Experiment}

In the wire house of the Institute of Soil and Environmental Sciences, University of Agriculture, Faisalabad, Pakistan, a pot experiment was performed to assess the potential for the combined use of strain AZ6 and organic waste for bio-activation of $\mathrm{Zn}$ to improve the physiological characteristics of maize. The soil used in the pot experiment was collected locally from the research farm. The pots were filled with air-dried, ground, sieved $(2 \mathrm{~mm})$ soil and analyzed for different physicochemical properties [16]. The treatments including control (without $\mathrm{Zn}$ and strain $\mathrm{AZ6}$ ), $\mathrm{ZnO}, \mathrm{ZnSO}_{4}, \mathrm{BOZ1}, \mathrm{BOZ2}, \mathrm{BOZ3}, \mathrm{BOZ} 4$, and ZSB were applied in pot soil and mixed thoroughly with an upper layer at the time of pot filling. The application rates for $\mathrm{BOZ1}, \mathrm{BOZ2}, \mathrm{BOZ3}$ and $\mathrm{BOZ} 4$ were 6.80, $7.65,8.74$, and $10.20 \mathrm{~kg} \mathrm{ha}^{-1}$, respectively. Total $\mathrm{Zn}$ in all the BOZ products was maintained up to $4.91 \mathrm{~kg} \mathrm{ha}^{-1}$. In the case of ZSB, surface disinfected maize seeds of cultivar Syngenta-NT662 were inoculated with strain AZ6 along with a mixture of sugar, clay, and grounded orange peel as reported by Baig and Verma [28]. The seeds were shaken well until the seeds emerged with a fine coating. The nutrient source of $\mathrm{N}$, phosphorus $(\mathrm{P})$, and potassium $(\mathrm{K})$ were applied at the rate of 175, 160, and $125 \mathrm{~kg} \mathrm{ha}^{-1}$, respectively, using Urea, Diammonium phosphate, and Sulfate of Potash, respectively. P and K fertilizer were applied at the time of sowing, whereas, $\mathrm{N}$ was applied in two splits i.e., half at the time of sowing and the remaining half after three weeks of sowing. As and where necessary, the plants were irrigated with tap water. After the two weeks of germination, only two comparatively healthy plants were maintained per pot. All the standard agronomic as well as insect and pest management strategies were performed. After two-months of germinations, the data regarding physiological parameters were recorded.

\section{Determination of Gas Exchange Attributes and Carbonic Anhydrase Activity}

Infrared gas analyzer model CIRAS-3 (PP System, Amesbury, MA, USA) with PLC 3 universal leaf cuvette was used to determine photosynthetic rate, transpiration rate, stomatal conductance, and vapor pressure deficit. The measurements were made in the morning from a fully expanded second top leaf with similar conditions as described by Mumtaz et al. [29]. The activity of carbonic anhydrase was calculated using the [30] methods. The second top-leaf samples were cut into small pieces $\left(1 \mathrm{~cm}^{2}\right)$ at a temperature below $25^{\circ} \mathrm{C}$. Leaf fragments of $200 \mathrm{mg}$ were suspended in a $0.2 \mathrm{M}$ hydrochloride solution and incubated for $20 \mathrm{~min}$ at $40^{\circ} \mathrm{C}$. After blotting, the pieces were moved into phosphate buffer test tubes ( $\mathrm{pH}$ 6.8), followed by the addition of alkaline bicarbonate solution and 0.002 percent blue bromothymol indicator. The tubes were incubated at $50^{\circ} \mathrm{C}$ for 20 minutes. Titration was performed with a mixture of reactions and $0.05 \mathrm{~N} \mathrm{HCl}$ using methyl red indicator. The results were expressed as fresh weight $\mathrm{s}^{-1}$ in terms of $\mu \mathrm{mol}\left(\mathrm{CO}_{2}\right) \mathrm{kg}^{-1}$.

\section{Determination of Leaf Chlorophyll Contents and Electrolyte Leakage}

In terms of SPAD value, the leaf chlorophyll contents of the top second completely expanded leaves from each plant were calculated using the chlorophyll meter (SPAD-502, Konica Minolta, Japan). As reported by Lutts et al. [31] electrolyte leakage has been used to test membrane permeability. Samples of leaves were washed three times with distilled water to extract contaminants from the surface debris. By cutting the young leaves, the leaf discs were prepared and placed in a closed vial containing $10 \mathrm{~mL}$ of distilled water, incubated for $24 \mathrm{~h}$ on a rotary shaker and autoclaved for $20 \mathrm{~min}$ at $120^{\circ} \mathrm{C}$. As reported by Lutts et al. [31] the electrolyte leakage was measured.

\section{Growth and Grain Yield Parameters}

The data of maize growth, yield, and grain quality of the current pot trial had already published in our previous study [16].

\section{Statistical Analysis}

The reported data was subject to one-way variance analysis (ANOVA) using Statistix v. 8.1 computer tools (Analytical Software, USA). The means of treatment is compared at a 5 percent probability level with the least significant difference (LSD) test [32].

\section{Results}

\section{Improvement in Gas-Exchange Attributes}

The application of various $\mathrm{BOZ}$ formulations showed a significant improvement in gas-exchange attributes including photosynthetic rate, transpiration rate, and stomatal conductance. The current study showed the photosynthetic rate in the range of 12.47 to $23.23 \mu \mathrm{mol} \mathrm{CO}_{2} \mathrm{~m}^{-2} \mathrm{~s}^{-1}$ through achieving the highest photosynthetic rate in $\mathrm{BOZ} 4$ and the lowest in control (Table 1). Among applied BOZ formulations, BOZ4 showed the highest increase in photosynthetic rate by $85 \%$ over control. This treatment also showed increased photosynthetic rate by $66 \%, 41 \%$, and $55 \%$ as compared to $\mathrm{ZnO}, \mathrm{ZnSO}_{4}$, and $\mathrm{ZSB}$, respectively. 
Table. 1. Effect of bioaugmented-organic matter coated with zinc oxide (BOZ) formulations on vapor pressure deficit, electrolyte leakage, SPAD value of maize leaves.

\begin{tabular}{|c|c|c|c|c|c|c|}
\hline Treatments & $\begin{array}{c}\text { Photosynthetic rate } \\
\left(\mu \mathrm{mol} \mathrm{CO} \mathrm{m}^{-2} \mathrm{~s}^{-1}\right)\end{array}$ & $\begin{array}{c}\text { Transpiration rate } \\
\left(\mathrm{mmol} \mathrm{H}_{2} \mathrm{O} \mathrm{m}^{-2} \mathrm{~s}^{-1}\right)\end{array}$ & $\begin{array}{c}\text { Stomatal conductance } \\
\left(\mathrm{mmol} \mathrm{m}^{-2} \mathrm{~s}^{-1}\right)\end{array}$ & $\begin{array}{c}\text { Vapor pressure } \\
\text { deficit }(\mathrm{kPa})\end{array}$ & $\begin{array}{c}\text { Electrolyte leakage } \\
(\%)\end{array}$ & SPAD value \\
\hline $\mathrm{Control}$ & $12.47 \mathrm{e}$ & $5.41 \mathrm{e}$ & $185.3 \mathrm{e}$ & $2.93 \mathrm{~d}$ & $60.33 \mathrm{a}$ & $30.20 \mathrm{f}$ \\
\hline $\mathrm{ZnO}$ & $14.00 \mathrm{de}$ & $6.01 \mathrm{e}$ & $190.3 \mathrm{de}$ & $3.06 \mathrm{~cd}$ & $58.00 \mathrm{ab}$ & $37.09 \mathrm{e}$ \\
\hline $\mathrm{ZnSO}_{4}$ & $16.50 \mathrm{c}$ & $8.12 \mathrm{c}$ & $212.6 \mathrm{bcd}$ & $3.45 \mathrm{bc}$ & $52.33 \mathrm{c}$ & $41.00 \mathrm{~cd}$ \\
\hline $\mathrm{BOZ1}$ & $15.08 \mathrm{~cd}$ & $7.75 \mathrm{~cd}$ & $203.0 \mathrm{cde}$ & $3.41 \mathrm{bc}$ & $48.00 \mathrm{~d}$ & $40.38 \mathrm{~cd}$ \\
\hline $\mathrm{BOZ2}$ & $17.23 \mathrm{bc}$ & $8.94 \mathrm{bc}$ & $219.3 \mathrm{abc}$ & $3.82 \mathrm{ab}$ & $38.67 \mathrm{e}$ & $42.41 \mathrm{c}$ \\
\hline $\mathrm{BOZ3}$ & $19.40 \mathrm{~b}$ & $9.64 \mathrm{~b}$ & $233.0 \mathrm{ab}$ & $3.97 \mathrm{a}$ & $35.67 \mathrm{f}$ & $45.29 \mathrm{~b}$ \\
\hline $\mathrm{BOZ4}$ & $23.23 \mathrm{a}$ & $11.28 \mathrm{a}$ & $242.3 \mathrm{a}$ & $4.21 \mathrm{a}$ & $33.33 \mathrm{f}$ & $50.08 \mathrm{a}$ \\
\hline $\mathrm{ZSB}$ & $15 \mathrm{~cd}$ & $6.58 \mathrm{de}$ & $197.6 \mathrm{cde}$ & $3.10 \mathrm{~cd}$ & $56.33 \mathrm{~b}$ & $38.12 \mathrm{de}$ \\
\hline
\end{tabular}

*Means followed by the same letters are not statistically different at $P<0.05$ according to the least significant difference (LSD) test

The sole application of $\mathrm{ZnO}, \mathrm{ZnSO}_{4}$, and $\mathrm{ZSB}$ also showed increase in photosynthetic rate by $12 \%, 32 \%$, and $20 \%$, respectively, over control. The similar treatments increased the stomatal conductance by $3 \%$, $15 \%$, and $7 \%$, respectively, as compared to control (Table 1). The control showed the lowest stomatal conductance of $185.3 \mathrm{mmol} \mathrm{m}^{-2} \mathrm{~s}^{-1}$. The application of BOZ4 showed a maximum increase in stomatal conductance of $242.3 \mathrm{mmol} \mathrm{m} \mathrm{m}^{-2} \mathrm{~s}^{-1}$ by $31 \%, 27 \%$, $23 \%$, and $14 \%$ as over control, $\mathrm{ZnO}, \mathrm{ZSB}$, and $\mathrm{ZnSO}_{4}$, respectively, and was statistically similar to BOZ3, however, showed highly significant stomatal conductance over control. On an average basis, the application of BOZ4 showed a maximum increase in transpiration rate up to $108 \%, 88 \%, 71 \%$, and $39 \%$ as compared to control, $\mathrm{ZnO}, \mathrm{ZSB}$, and $\mathrm{ZnSO}_{4}$, respectively (Table 1). The sole application of $\mathrm{ZnO}, \mathrm{ZnSO}_{4}$, and $\mathrm{ZSB}$ also promoted a transpiration rate up to $12 \%, 32 \%$, and $20 \%$, respectively, as compared to control.

\section{Effect on Electrolyte Leakage and SPAD Value}

The application of $\mathrm{BOZ}$ formulation resulted in a significant reduction in electrolyte leakage as demonstrated in Table 1. Maximum reduction in electrolyte leakage was observed with the application of BOZ4 (45\%) followed by BOZ3, BOZ2, and BOZ1 that showed $41 \%, 36 \%$, and $21 \%$, respectively, over control. BOZ4 application demonstrated $43 \%, 36 \%$, and $41 \%$ reduction in electrolyte leakage than $\mathrm{ZnO}, \mathrm{ZnSO}_{4}$, and ZSB, respectively. The application of BOZ4 resulted in highest increase in SPAD value up to $66 \%, 35 \%, 22 \%$, and $31 \%$, respectively, as compared to control, $\mathrm{ZnO}$, $\mathrm{ZnSO} 4$, and ZSB, respectively (Table 1). While, the sole application of $\mathrm{ZnO}, \mathrm{ZnSO}_{4}$, and $\mathrm{ZSB}$ increased the SPAD value up to $23 \%, 36 \%$, and $26 \%$, respectively, as over control.

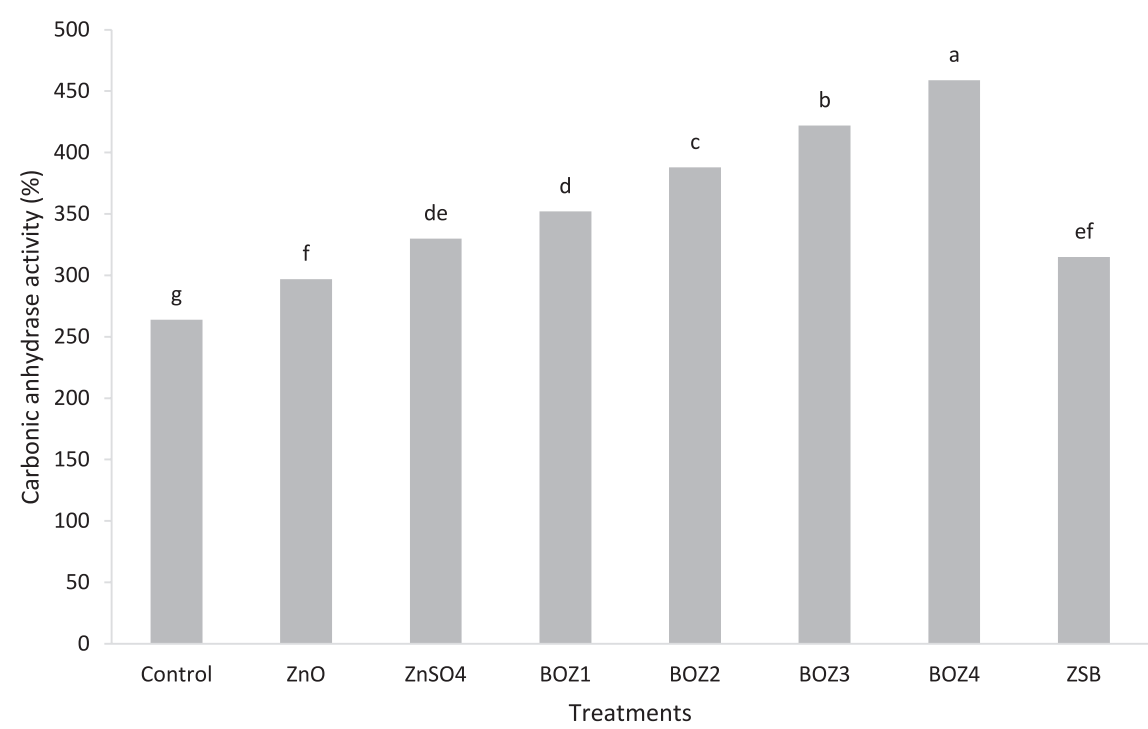

Fig. 1. Effect of bioaugmented-organic matter coated with zinc oxide (BOZ) formulations on carbonic anhydrase activity in maize. 


\section{Increase in Carbonic Anhydrase Activity and Vapor Pressure Deficit}

A significant increase in carbonic anhydrase activity was observed with the application of $\mathrm{BOZ}$ formulations (Fig. 1). Results revealed that the application of $\mathrm{BOZ} 4, \mathrm{BOZ} 3, \mathrm{BOZ2}, \mathrm{BOZ1}$ resulted in $74 \%, 60 \%, 47 \%$, and $33 \%$, respectively, increase in carbonic anhydrase activity as compared to control. Further, the application of BOZ4 showed increase by $55 \%, 39 \%$, and $46 \%$ over $\mathrm{ZnO}, \mathrm{ZnSO}_{4}$, and $\mathrm{ZSB}$, respectively. The application of $\mathrm{ZnO}, \mathrm{ZnSO}_{4}$, and ZSB also promoted carbonic anhydrase activity up to $13 \%, 25 \%$, and $19 \%$, respectively, over control. These treatments also showed increase in vapor pressure deficit by $4 \%, 18 \%$, and $6 \%$, respectively, as compared to control (Table 1). The increase with BOZ formulation was ranked $\mathrm{BOZ} 4>\mathrm{BOZ} 3>\mathrm{BOZ} 2>\mathrm{BOZ} 1$ by $44 \%, 36 \%$, $30 \%$, and $16 \%$, respectively, higher as over control. The increase in vapor pressure deficit due to $\mathrm{BOZ} 4$ was also higher than $\mathrm{ZnO}, \mathrm{ZnSO}_{4}$, and $\mathrm{ZSB}$ by $38 \%, 22 \%$, and $36 \%$, respectively.

\section{Discussion}

Zinc is the most important micronutrient for crop physiology. Its deficiency affects cereals crop physiology as reported by several researchers $[33,34$, 35]. Moreover, $\mathrm{Zn}$ deficiency in cereals is observed due to the limited availability of $\mathrm{Zn}$ in the soil. Mostly, $\mathrm{Zn}$ the applied chemical fertilizers become fixed in alkaline soils due to the higher soil $\mathrm{pH}$. An increase in plant available $\mathrm{Zn}$ content in soils by the inoculation of different ZSB was reported by Mumtaz et al. [36]. In the current study, four $\mathrm{BOZ}$ formulations were prepared by using orange peel augmented with Bacillus sp. AZ6 and mixed with bulk $\mathrm{ZnO}$ powder and their effectiveness to improve maize physiology was observed as compared to control. The results revealed that the use of biologically activated $\mathrm{Zn}$ can significantly increase the physiological attributes of maize as compared to the chemical $\mathrm{Zn}$ sources and the inoculation with ZSB strain. Among the biologically activated $\mathrm{Zn}$ formulations, BOZ4 showed a better increase in physiological attributes of maize as compared to $\mathrm{BOZ1}, \mathrm{BOZ2}$, and $\mathrm{BOZ} 3$ formulations. The same products were previously applied in pot and field trial conditions by our research group and reported their effectiveness to improve maize growth, yield, and biofortification [16, 17]. Similarly, Nazir et al. [37] and Nazir et al. [18] also reported an increase in rice and wheat productivity and biofortification through the application of urea coated with bio-activated $\mathrm{ZnO}$ formulations. Ain et al. [19] also reported the alleviation of salinity stress in wheat through the application of urea coated with bioaugmented $\mathrm{ZnO}$.

In the current study, strain Bacillus sp. AZ6 was used to augment organic matter (orange peel) and to chelate the $\mathrm{ZnO}$. This strain is $\mathrm{Zn}$ solubilizing and possesses multiple plant growth-promoting characteristics as reported by Hussain et al. [14]. Zn deficiency in soils results in human deficiency. The ZSB solubilizes the insoluble $\mathrm{Zn}$ in the soil, making it available to plants and, finally, to humans. Inoculation of Zn-solubilizing bacteria results in an increase in plant height in a variety of crops. In rice, Acinetobacter sp. and Serratia sp. inoculation increased plant height and root volume, while Enterobacter cloacae, Rhizobium sp., and Pantoea agglomerans increased wheat shoot and root biomass and $\mathrm{Zn}$ content [38, 39]. Plant height, number of branches per plant, stem girth, and total biomass were all increased after inoculation with $\mathrm{Zn}$-solubilizing Bacillus sp. Vidyashree et al. [40] reported the chelation of insoluble $\mathrm{Zn}$ with ethylenediaminetetraacetic acid produced by Pseudomonas sp., Azospirillum lipoferum, and Agrobacterium sp. that promoted the sustainable $\mathrm{Zn}$ availability in rice. The ZSB strains increase root growth in terms of root length, surface area, and root hair that causes increase in nutrient utilization. In the present study, strain AZ6 could endorse plant physiology through producing auxin, ACC-deaminase activity, siderophores production, and solubilization of phosphate and $\mathrm{Zn}$ as reported by Hussain et al. [14]. The chelating complexes are synthesized or unconstrained into the rhizosphere by plant roots and potential rhizosphere microflora to chelate $\mathrm{Zn}$ and increase its utilization in the plant root zone. Bacterial metabolites form a complex with $\mathrm{Zn}^{2+}$ and reduce its reaction with soil. In combination with $\mathrm{ZnSO}_{4}, \mathrm{Zn}$ solubilizing bacteria and Arbuscular mycorrhizal (AM) fungi improve $\mathrm{Zn}$ transformation, nutrient absorption, yield, and $\mathrm{Zn}$ content of stover. The insoluble nutrient in the soil was being solubilized by zinc-solubilizing bacteria. The immobile nutrient in the soil was being mobilized by AM fungi. The plant's growth, yield, dry matter production, and $\mathrm{Zn}$ content were all improved by microbial inoculation alone or in combination with Zn fertilizer [41]. Similarly, Othman et al. [38] reported that inoculation with ZSB strains promoted root weight, length, and root volume, and the biofortification of $\mathrm{Zn}$.

In the present study, we attempted to increase the availability of $\mathrm{Zn}$ through the application of $\mathrm{BOZ4}$ formulation as reported in our earlier study [16, 17]. The application of BOZ4 formulations significantly promoted the gas exchange characteristic of maize that might be due to bioactivation of $\mathrm{ZnO}$ through strain AZ6 and organic matter. The bioactivation of $\mathrm{ZnO}$ could be attained through reaction with organic acid and chelating agents produced from bacterial strains and the decomposition of organic acids. $\mathrm{ZnO}$ bioactivation dissolves the compounds and increases $\mathrm{Zn}$ bioavailability that has a potential role to increase gas exchange attributes and CA activity. In the present study, the application of $\mathrm{BOZ} 4$ products significantly promoted CA activity, photosynthesis, transpiration rate, stomatal regulation, and chlorophyll contents. The increase in photosynthetic activity due to the application of BOZ4 formulation might due 
to the effect of higher CA activity. Moreover, the increase in net photosynthesis may be attributed to an increase in chlorophyll contents that might be true in the current study that application of BOZ4 product promoted Zn uptake [16, 17] that causes an increase in net photosynthesis, CA activity, and chlorophyll contents. Zinc solubilizing bacteria play an important role in plant growth, owing to the direct or indirect mechanisms that involve the production of Indole Acetic Acid (IAA), organic acids, Hydrocyanic acid (HCN), ACC deaminase, siderophores, mineralization of various minerals such as $\mathrm{P}$ liquefaction and $\mathrm{Zn}$ solubilization, all of which are important for plant development [42, 43]. The increase in gas exchange attributes, CA activity, chlorophyll contents due to increased uptake of $\mathrm{Zn}$ was previously supported by Jan et al. [44], Cao et al. [45], Aslam et al. [46], Wang et al. [47] and documented the improvement of wheat's physiological qualities under drought stress through the application of endophytic bacteria containing CA activity. Thus, $\mathrm{ZnO}$ bio-activation with ZSB may serve as an effective and cost-effective technique to improve the physiological parameters of maize.

\section{Conclusion}

Bio-activated $\mathrm{Zn}$ formulations potentially enhanced the physiological attributes of maize over control, $\mathrm{ZnSO}_{4}, \mathrm{ZnO}$, and ZSB strain. Among formulated bioactivated $\mathrm{Zn}$ products, BOZ4 was a more effective treatment as compared to $\mathrm{BOZ3}, \mathrm{BOZ2}$, BOZ1 formulations. The combined use of organic matter supplemented with inexpensive $\mathrm{Zn}$ source in terms of $\mathrm{ZnO}$ and $\mathrm{ZSB}$ strain in the BOZ4 formulation could be a novel approach to enhance $\mathrm{Zn}$ availability, organic matter contents, and to enrich the rhizosphere with beneficial rhizobacteria. Simultaneously, it is also a cost-effective and environmentally friendly approach for sustainable crop production.

\section{Acknowledgments}

The authors are grateful for the provision of research facilities by the Institute of Soil \& Environmental Sciences, University of Agriculture, Faisalabad, Pakistan.

\section{Conflict of Interest}

The authors declare no conflict of interest

\section{References}

1. TOOR M.D., ADNAN M., JAVED M.S., HABIBAH U., ARSHAD A., DIN M.M., AHMAD R. Foliar application of $\mathrm{Zn}$ : Best way to mitigate drought stress in plants; A review. Int. j. appl. 6 (8), 16, 2020.

2. GÓMEZ-MUÑOZ B., LEKFELDT J.D., MAGID J., JENSEN L.S., DE NEERGAARD A. Seed treatment with Penicillium sp. or $\mathrm{Mn} / \mathrm{Zn}$ can alleviate the negative effects of cold stress in maize grown in soils dependent on soil fertility. J Agron Crop Sci J Agron Crop Sci. 204 (6), 603, 2018.

3. RIZWAN M., ALI S., ALI B., ADREES M., ARSHAD M., HUSSAIN, A., WARIS, A. A. Zinc and iron oxide nanoparticles improved the plant growth and reduced the oxidative stress and cadmium concentration in wheat. Chemosphere, 214, 269, 2019.

4. STURIKOVA H., KRYSTOFOVA O., HUSKA D., ADAM V. Zinc, zinc nanoparticles and plants. J. Hazard. Mater. 349, 101, 2018.

5. KNEZ M., STANGOULIS J.C., GLIBETIC M., TAKO E. The linoleic acid: dihomo- $\gamma$-linolenic acid ratio (LA: DGLA - an emerging biomarker of Zn status. Nutrients, 9 (8), 825, 2017.

6. KHATUN M.A., HOSSAIN M.M., BARI M.A., ABDULLAHIL K.M., PARVEZ M.S., ALAM M.F., KABIR A.H. Zinc deficiency tolerance in maize is associated with the up-regulation of $\mathrm{Zn}$ transporter genes and antioxidant activities. Plant Biol. 20 (4), 765, 2018.

7. DIMARIO R., CLAYTON H., MUKHERJEE A., LUDWIG M., MORONEY J.V. Plant carbonic anhydrases: structures, locations, evolution, and physiological roles. Mol. Plant. 10, 30, 2017.

8. TEN BERGE H.F., HIJBEEK R., VAN LOON M.P., RURINDA J., TESFAYE K., ZINGORE S., VAN ITTERSUM M.K. Maize crop nutrient input requirements for food security in sub-Saharan Africa. Global Food Security. 23, 9, 2019.

9. OHLY H., BROADLEY M.R., JOY E.J.M., KHAN M.J., MCARDLE H., ZAMAN M., LOWE N. The BiZiFED project: Biofortified zinc flour to eliminate deficiency in Pakistan. Nutrition bulletin, 44 (1), 60, 2019.

10. MONTALVO D., DEGRYSE F., DA SILVA R.C., BAIRD R., MCLAUGHLIN M.J. Agronomic effectiveness of zinc sources as micronutrient fertilizer. In Advances in agronomy, Academic Press. 139, 215, 2016.

11. KUMAR A., S. DEWANGAN, P., BAHADUR LAWATE, I., LAWATE, I. PRAJAPATI LAWATE, I. ZincSolubilizing Bacteria: A Boon for Sustainable Agriculture. In Plant Growth Promoting Rhizobacteria for Sustainable Stress Management, 139-55. Singapore: Springer. 2019.

12. MAZUMDAR D., SAHA S.P., GHOSH S. Isolation, screening and application of a potent PGPR for enhancing growth of Chickpea as affected by nitrogen level. Int. J. Veg. Sci. 26 (4), 1, 2019.

13. PRASAD R., SHIVAY Y.S., KUMAR D. Interactions of zinc with other nutrients in soils and plants - a Review. Indian Journal of Fertilizers. 12, (5), 16, 2016.

14. HUSSAIN A., ARSHAD M., ZAHIR Z.A., ASGHAR M. Prospects of zinc solubilizing bacteria for enhancing growth of maize. Pakistan journal of agricultural sciences. 52 (4), 123, 2015.

15. MUMTAZ M.Z., AHMAD M., JAMIL M., HUSSAIN T. Zinc solubilizing Bacillus spp. potential candidates for biofortification in maize. Microbiological research. 202, 51, 2017.

16. HUSSAIN A., ZAHIR Z.A., ASGHAR H.N., IMRAN M., AHMAD M., HUSSAIN S. Integrating the potential of Bacillus sp. Az6 and organic waste for zinc oxide bioactivation to improve growth, yield and zinc content of 
maize grains. Pakistan Journal of Agricultural Sciences. 57 (1), 2020 a.

17. HUSSAIN A., ZAHIR Z.A., DITTA A., TAHIR M.U., AHMAD M., MUMTAZ M.Z., HUSSAIN S. Production and Implication of Bio-Activated Organic Fertilizer Enriched with Zinc-Solubilizing Bacteria to Boost up Maize (Zea mays L.) Production and Biofortification under Two Cropping Seasons. Agronomy basel. 10 (1), 39, 2020 b.

18. NAZIR Q., HUSSAIN A., MUMTAZ M.Z., NIAZ A., ARIF M., AFTAB M., AZIZ T. Efficiency of Various Formulations of Urea Coated with Bioaugmented (Bacillus sp.) $\mathrm{ZnO}$ to Improve Growth, Yield and $\mathrm{Zn}$ Contents of Wheat Grains. Polish Journal of Environmental Studies. 30, (1), 803, 2020.

19. AIN N.U., NAVEED M., HUSSAIN A., MUMTAZ M.Z., RAFIQUE M., BASHIR M.A., SIDDIQUI M.H. Impact of Coating of Urea with Bacillus-Augmented Zinc Oxide on Wheat Grown under Salinity Stress. Plants. 9, (10), 1375, 2020.

20. FEIGL G., MOLNÁR Á., SZÖLLÖSI R., ÖRDÖG A., TÖRÖCSIK K., OLÁH D., KOLBERT, Z. Zinc-induced root architectural changes of rhizotron-grown B. napus correlate with a differential nitro-oxidative response. Nitric Oxide. 90, 55, 2019.

21. ZHAO Q.Y., XU S.J., ZHANG W.S., ZHANG Z., YAO Z., CHEN X.P., ZOU C.Q. Identifying key drivers for geospatial variation of grain micronutrient concentrations in major maize production regions of China. Environ Pollu. 266, 115, 2020.

22. HOU S., ZHENG N., TANG L., JI X., LI Y. Effect of soil $\mathrm{pH}$ and organic matter content on heavy metals availability in maize (Zea mays L.) rhizospheric soil of non-ferrous metals smelting area. Environ. Monit. Assess. 191 (10), 1, 2019.

23. KHANGHAHI M.Y., RICCIUTI P., ALLEGRETTA I., TERZANO R., CRECCHIO C. Solubilization of insoluble zinc compounds by zinc solubilizing bacteria (ZSB) and optimization of their growth conditions. Environ. Sci. Pollut. Res. 25 (26), 25862, 2018.

24. SEHAR N.U., AHAMD M., AKHTAR M.F.Z., JAMIL M., LATIF M., AHMAD I. Pesticide tolerant plant growth promoting rhizobacteria with diverse traits isolated from rhizosphere of okra. Soil Environ. 34 (2), 111, 2015.

25. PRASAD M., SRINIVASAN R., CHAUDHARY M., CHOUDHARY M., JAT L.K. Plant Growth Promoting Rhizobacteria (PGPR) for Sustainable Agriculture: Perspectives and Challenges. In PGPR Amelioration in Sustainable Agriculture, United Kingdom: Woodhead Publishing. 129, 2019.

26. MANOJ S.R., KARTHIK C., KADIRVELU K., ARULSELVI P.I., SHANMUGASUNDARAM T., BRUNO B., RAJKUMAR M. Understanding the molecular mechanisms for the enhanced phytoremediation of heavy metals through plant growth promoting rhizobacteria: A review. J. Environ. Manage. 254, 109, 2020.

27. WOLF B. A comprehensive system of leaf analyses and its use for diagnosing crop nutrient status. Communications in Soil Science and Plant Analysis. 13, (12), 1035, 1982.

28. BAIG R.N., VARMA R.S. Alternative energy input: mechanochemical, microwave and ultrasound-assisted organic synthesis. Chemical Society Reviews. 41 (4), 1559, 2012.

29. MUMTAZ M.Z., SAQI M., ABBAS G., AKHTAR J., UI-QAMAR Z. Drought Stress Impairs Grain Yield and Quality of Rice Genotypes by Impaired Photosynthetic Attributes and K Nutrition, Rice Science. 27 (1), 5, 2020.
30. DWIVEDI R.S., RANDHAWA N.S. Evaluation of rapid test for hidden hunger of zinc in plants. Plant Soil. 40, 445, 1974.

31. LUTTS, S., KINET, J.M., BOUHARMONT, J. Changes in plant response to $\mathrm{NaCl}$ during development of rice (Oryza sativa $\mathrm{L}$.) varieties differing in salinity resistance. Journal of Experimental Botany. 46 (12), 1843, 1995.

32. STEEL R.G.D., TORRIE J.H. DICKY D.A. Principles and Procedures of Statistics, A Biometrical Approach. $3^{\text {rd }}$ Edition, McGraw Hill, Inc. Book Co., New York. 352, 1997.

33. MATTIELLO E.M., RUIZ H.A., NEVES J.C., VENTRELLA M.C., ARAÚJO W.L. Zinc deficiency affects physiological and anatomical characteristics in maize leaves. Journal of plant physiology. 183, 138, 2015.

34. LEE J.S., SAJISE A.G., GREGORIO G.B., KRETZSCHMAR T., ISMAIL A.M., WISSUWA M. Genetic dissection for zinc deficiency tolerance in rice using bi-parental mapping and association analysis. Theoretical and Applied Genetics. 130, (9), 1903, 2017.

35. KHATUN M.A., HOSSAIN M.M., BARI M.A., ABDULLAHIL K.M., PARVEZ M.S., ALAM M.F., KABIR A.H. Zinc deficiency tolerance in maize is associated with the up-regulation of $\mathrm{Zn}$ transporter genes and antioxidant activities. Plant Biology. 20 (4), 765, 2018.

36. MUMTAZ Z.M., AHMAD M. JAMIL., HUSSAIN T. Zinc solubilizing Bacillus spp. potential candidates for biofortification in maize. Microbiol. Res. 202 (51), 60, 2017.

37. NAZIR Q., ARSHAD M., AZIZ T., SHAHID M. Influence of zinc impregnated urea on growth, yield and grain zinc in rice (Oryza sativa). Int. J. Agric. Biol. 18, 1195, 2016.

38. OTHMAN N.M., OTHMAN R., EDAROYATI P., WAHAB M. Effects of root colonization by zinc solubilizing bacteria on rice plant (Oryza sativa MR219) growth. Agric. Nat. Resour. 51 (6), 532, 2017.

39. KAMRAN S., SHAHID I., BAIG D.N., RIZWAN M., MALIK K.A., MEHNAZ S. Contribution of zinc solubilizing bacteria in growth promotion and zinc content of wheat. Front. microbiol. 2017.

40. VIDYASHREE D.N., MUTHURAJU R., PANNEERSELVAM P. Evaluation of zinc solubilizing bacterial (ZSB) strains on growth, yield and quality of tomato (Lycopersicon esculentum). Int J Curr Microbiol Appl Sci. 7 (4), 1493, 2018.

41. AYYAR S., APPAVOO S., BASKER M., PANDIYARAJAN P., KAVIMANI R. Effect of zinc and microbial inoculation on soil enzyme activities for maize (Zea mays L.) in black soil. Int J Curr Microbiol Appl Sci. 8 (08), 1804, 2019.

42. KARNWAL A., DOHROO A. Effect of maize root exudates on indole-3-acetic acid production by rice endophytic bacteria under influence of L-tryptophan. F1000 Research 7, 112, 2018.

43. MAZUMDAR D., SAHA S.P., GHOSH S. Isolation, screening and application of a potent PGPR for enhancing growth of Chickpea as affected by nitrogen level. Int. J. Veg. Sci. 26 (4), 1, 2019.

44. JAN M., ANWAR-UL-HAQ M., SHAH A.N., YOUSAF M., IQBAL J., LI, X WANG D., FAHAD S. Modulation in growth, gas exchange, and antioxidant activities of salt-stressed rice (Oryza sativa L.) genotypes by zinc fertilization. Arabian Journal of Geosciences. 12 (24), 775, 2019.

45. CAO M.L., LI Y.X., DU H.L. Effects of exogenous zinc on the photosynthesis and carbonic anhydrase activity of 
millet (Setaria italica L.). Photosynthetica. 58 (3), 712, 2020.

46. ASLAM A., AHMAD ZAHIR Z., ASGHAR H.N., SHAHID, M. Effect of carbonic anhydrase-containing endophytic bacteria on growth and physiological attributes of wheat under water-deficit conditions. Plant Production Science. 21, (3), 244, 2018.
47. WANG X., FAN J., XING Y., XU G., WANG H., DENG J., WANG Y., ZHANG F., LI P., LI Z. The effects of mulch and nitrogen fertilizer on the soil environment of crop plants. Advances in agronomy. 153, 121, 2019. 